\title{
PENGARUH KEAKTIFAN BELAJAR SISWA MELALUI PENERAPAN MODEL PEMBELAJARAN KOOPERATIF TIPE TEAM ASSISTED INDIVIDUALIZATION (TAI) TERHADAP HASIL BELAJAR MATEMATIKA SISWA KELAS VII SMP NEGERI 4 SATAP BUNGORO
}

\author{
Herman Alimuddin \\ Dosen Pendidikan Matematika, STKIP Andi Matappa Pangkep \\ Email: herman.alimuddin@stkip-andi-matappa.ac.id
}

\begin{abstract}
ABSTRAK
Jenis penelitian ini adalah penelitian Eksperimen yang bersifat korelasi dengan menggunakan analisis regresi linear sederhana yang bertujuan untuk mengetahui ada tidaknya pengaruh keaktifan belajar siswa akibat penerapan model pembelajaran kooperatif tipe Team Assisted Individualization (TAI) terhadap hasil belajar matematika. Populasi dalam penelitian ini adalah seluruh kelas VII SMP Negeri 4 Satap Bungoro tahun ajaran 2017-2018 yang berjumlah 27 siswa, dengan mengambil sampel dengan menggunakan teknik “simple jenuh”. Pegumpulan data menggunakan lembar observasi keaktifan dan tes tertulis. Data dianalisis dengan analisis statistik deskriptif dan statistik inferensial

Keaktifan siswa pada saat pembelajaran termasuk kategori aktif dengan persentase $55,55 \%$ dan skor rata-rata 75,26, Hasil belajar matematika siswa termasuk kategori sangat baik dengan persentase 51,82\% dan skor rata-rata 80,56. Uji hipotesis diperoleh nilai $F_{\text {hitung }}>F_{\text {tabel }}(6,965>4,24)$, yang menunjukkan bahwa $H_{0}$ ditolak dan $H_{1}$ diterima yang berarti terdapat perbedaan hasil belajar peserta didik sebelum penerapan model pembelajaran Kooperatif Tipe Team Assisted Individualization (TAI). Berdasarkan hasil tersebut maka dapat disimpulkan bahwa penerapan model pembelajaran Kooperatif Tipe Team Assisted Individualization (TAI) terjadi peningkatan hasil belajar pada peserta didik kelas VII SMP Negeri 4 Satap Bungoro.
\end{abstract}

Kata Kunci : Keaktifan, Hasil Belajar Matematika, TAI

\section{PENDAHULUAN}

Pembelajaran matematika belum menunjukkan hasil yang optimal. Hal ini terlihat dari rendahnya hasil belajar matematika pada siswa. Hal ini dibuktikan dengan hasil ulangan siswa yang berdasarkan data tahun 2016/2017 terlihat bahwa 60\% siswa belum mencapai KKM yaitu 75 yang telah ditetapkan. Agar sesuai dengan tujuan pendidikan yang diharapkan maka pembelajaran matematika di sekolah diselenggarakan dengan mengacu pada kurikulum yang telah ditetapkan, diharapkan mampu memberikan jawaban terhadap beberapa permasalahan yang terjadi ditingkat sekolah serta siswa diarahkan untuk lebih aktif dan kreatif dalam menanggapi setiap pelajaran yang diajarkan. Belajar 
yang lebih efektif hanya mungkin, jika siswa itu sendiri larut aktif dalam merumuskan serta memecahkan berbagai masalah.

Keaktifan siswa merupakan salah satu prinsip utama dalam proses pembelajaran. Belajar adalah berbuat, oleh karena itu tidak ada belajar tanpa aktivitas, dimana aktivitas siswa memiliki peranan penting dalam proses pembelajaran, pengalaman belajar hanya dapat diperoleh jika siswa aktif berinteraksi dengan lingkungan sekitarnya. Menurut Rosalia ( 2005: 4 ), Keaktifan siswa selama proses belajar mengajar merupakan salah satu indikator adanya keinginan atau motivasi siswa untuk belajar. Siswa dikatakan memiliki keaktifan apabila ditemukan ciri-ciri perilaku seperti, sering bertanya kepada guru atau siswa lain, mau mengerjakan tugas yang diberikan guru, mampu menjawab pertanyaan, senang diberi tugas belajar dan lain sebagainya. Seorang guru perlu merancang kegiatan pembelajaran yang memungkinkan siswa untuk melakukan kegiatan secara aktif. Siswa akan belajar secara aktif apabila rancangan pembelajaran yang disusun oleh guru mengharuskan siswa untuk melakukan kegiatan dalam belajar.

Sebagai upaya meningkatkan keaktifan siswa kita harus memilih model pembelajaran yang tepat untuk menyampaikan berbagai konsep dalam pembelajaran yang memberikan kesempatan bagi siswa untuk bertukar pendapat, bekerjasama dengan teman, berinteraksi dengan guru dan merespon pemikiran siswa lain sehingga siswa seperti menggunakan dan mengingat konsep tersebut.

Penerapan metode-metode mengajar yang bervariasi akan dapat mengurangi kejenuhan siswa dalam menerima pelajaran. Salah satu model pembelajaran yang melibatkan keaktifan siswa adalah model pembelajaran TAI, model pembelajaran ini memungkinkan siswa untuk aktif dalam pembelajaran, mengembangkan pengetahuan, sikap dan keterampilan secara mandiri serta terciptanya kondisi pembelajaran yang kondusif bagi siswa untuk belajar.

Model Pembelajaran kooperatif Tipe TAI ( Team Assisted Individualization ) ini dikembangkan oleh Slavin. Menurut Slavin (2005) tipe ini mengkombinasikan keunggulan pembelajaran kooperatif dan pembelajaran individual. Tipe ini dirancang untuk mengatasi kesulitan belajar siswa secara individual. Oleh karena itu kegiatan pembelajarannya lebih banyak digunakan untuk pemecahan masalah, ciri khas pada model pembelajaran TAI ini adalah setiap siswa secara individual belajar materi pembelajaran yang sudah dipersiapkan oleh guru. Hasil belajar individual dibawa kekelompok-kelompok untuk didiskusikan dan saling dibahas oleh anggota kelompok, 
dan semua anggota kelompok bertanggung jawab atas keseluruhan jawaban sebagai tanggung jawab bersama.

Hasil observasi di SMP Negeri 4 Satap Bungoro menunjukkan bahwa siswa masih terfokus pada guru meskipun guru tersebut telah menerapkan model pembelajaran kooperatif, namun siswa belum sepenuhnya terlibat secara aktif dalam pembelajaran disebabkan oleh siswa yang kurang pandai secara tidak langsung akan menggantung pada siswa yang pandai, siswa juga kurang bersaing dalam kelompok, adanya anggota kelompok yang pasif dan tidak mau berusaha serta hanya mengandalkan teman, guru matematika di SMP Negeri 4 Satap Bungoro untuk kelas VII juga menambhakan bahwa, permasalahan yang muncul dalam pembelajaran matematika, antara lain : 1) Siswa kurang aktif dalam mengikuti pembelajaran keaktifan didominasi oleh beberapa siswa saja, 2) Siswa jarang mengajukan pertanyaan, meskipun guru sering memberi kesempatan kepada siswa untuk bertanya tentang hal-hal yang belum dipahami, 3) Sifat individual siswa masih tinggi sehingga enggan untuk belajar kelompok atau diskusi kelompok.

Dalam pembelajaran matematika diharapkan guru mampu menciptakan suasana pembelajaran yang menarik dan dapat meningkatkan keaktifan dan hasil belajar siswa terhadap pembelajaran matematika. Salah satu upaya yang dapat dilakukan adalah dengan memilih model pembelajaran yang menciptakan interaksi antar guru dan siswa, serta antar sesama siswa karena pembelajaran tidak lagi berpusat pada guru.

Salah satu alternatif untuk mengatasi masalah yang ada berupa penerapan model pembelajaran yang lebih mengutamakan keaktifan siswa dan memberi kesempatan siswa untuk mengembangkan potensinya secara maksimal. Model pembelajaran yang dimaksud adalah model pembelajaran kooperatif. Model pembelajaran kooperatif sangat cocok diterapkan pada pembelajaran matematika karena dalam mempelajari matematika tidak cukup dengan hanya mengetahui dan menghafal konsep-konsep matematika tetapi juga dibutuhkan suatu pemahaman serta kemampuan menyelesaikan persoalan matematika dengan baik dan benar.

Miftahul (2011) mengemukakan bahwa dalam model pembelajaran TAI, siswa dikelompokkan berdasarkan kemampuannya yang beragam. Masing-masing kelompok terdiri dari 5 siswa dan ditugaskan untuk menyelesaikan materi pembelajaran atau PR.

Nurasma (2006) mengemukakan bahwa kegiatan pembelajaran dengan model pembelajaran TAI tidak sama dengan kegiatan pembelajaran pada model pembelajaran STAD dan TGT, TAI terikat pada serangkaian materi pelajaran yang khas dan memiliki petunjuk pelaksanaan sendiri. 
Model pembelajaran kooperatif yang cocok untuk mata pelajaran matematika salah satunya adalah model pembelajaran kooperatif tipe Team Assisted Individualization (TAI), dimana model pembelajaran ini merupakan salah satu alternatif model pembelajaran yang menuntut siswa untuk aktif. Serta Team Assisted Individualization (TAI) merupakan model pembelajaran yang menarik, karena menerapkan gabungan dari dua hal yaitu belajar dengan kemampuan masing-masing individu dan belajar kelompok. Melalui model pembelajaran kooperatif tipe Team Assisted Individualization (TAI) siswa dituntut untuk dapat bertanggung jawab terhadap kelompok dan diri sendiri. Setelah siswa mempelajari materi pelajaran secara individu, siswa harus berdiskusi dalam kelompok untuk memecahkan masalah yang ada, serta model pembelajaran kooperatif tipe Team Assisted Individualization (TAI) siswa dapat termotivasi untuk bisa berprestasi lebih tinggi, saling membantu satu sama lain dalam menghadapi masalah dan saling memberi dorongan untuk maju. Siswa juga merasa senang dalam proses pembelajaran karena mereka semakin tertantang dengan persoalan-persoalan matematika baru yang mereka belum pernah temui sebelumnya sehingga siswa terpicu untuk dapat menyelesaikan masalah yang ada.

\section{METODE PENELITIAN}

Jenis penelitian yang digunakan adalah penelitian eksperimen bersifat korelasi yang bertujuan untuk mengetahui apakah keaktifan belajar siswa melalui penerapan model pembelajaran kooperatif tipe Team Assisted Individualization (TAI) mempunyai pengaruh terhadap hasil belajar matematika siswa dengan menggunakan analisis regresi linear sederhana, yang hanya melibatkan 1 kelas sebagai sampel penelitian. Dimana analisis regresi linear sederhana digunakan untuk mengukur pengaruh antara variabel bebas terhadap variabel terikat.

Desain penelitian ini dapat di gambarkan sebagai berikut :

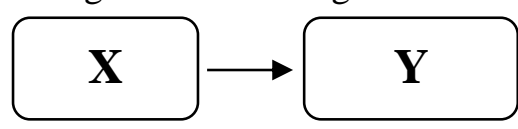

Gambar 1. Bagan Desain Penelitian

$\mathrm{X}=$ Keaktifan belajar siswa dengan penerapan model pembelajaran

Kooperatif tipe TAI (Assistend Individualization)

$\mathrm{Y}=$ Hasil belajar matematika siswa

Penelitian ini dilaksanakan pada semester ganjil tahun ajaran 2017/2018 yang berlangsung pada tanggal 01 Agustus sampai 16 Agustus 2017. Populasi dalam 
penelitian ini adalah seluruh siswa kelas VII SMP Negeri 4 Satap yang terdiri dari berjumlah 27 siswa

Dari pertimbangan tersebut terpilih 27 siswa yang menjadi sampel penelitian dengan menerapkan model pembelajaran Koopertaif tipe Team Assistead Individualization (TAI). Adapun instrumen penelitian yang akan digunakan adalah sebagai berikut:

A. Tes Hasil Belajar

Tes hasil belajar berupa soal essai untuk memperoleh data tentang hasil belajar matematika

B. Aktifitas Siswa

Lembar observasi adalah lembar kerja yang berfungsi untuk mengobservasi dan mengukur tingkat keberhasilan atau tercapainya tujuan pembelajaran pada kegiatan belajar mengajar dikelas.

Analisis data yang digunakan dalam penelitian ini adalah:

\section{A. Statistik deskriptif}

Statistik deskriptif digunakan untuk mendeskripsikan hasil belajar siswa setelah diajar dengan model pembelajaran kooperatif tipe Team Assistend Individualization (TAI), dengan menggunakan program SPSS versi 21 sebagai pembuktian analisis data. Data hasil belajar matematika tersebut di deskripsikan dalam bentuk nilai tertinggi, nilai terendah, nilai rata-rata, standar deviasi dan varians. Guna mendapatkan gambaran yang jelas tentang hasil belajar matematika siswa di kelas.

Jenis data berupa hasil belajar selanjutnya dilakukan dengan pengkategorian berdasarkan teknik kategorisasi menurut Asmawi Zainul sebagai berikut:

Tabel 1. Kategori Penilaian Hasil Belajar

\begin{tabular}{cc}
\hline Skor & Kategori \\
\hline $80-100$ & Sangat Baik \\
\hline $70-79$ & Baik \\
\hline $60-69$ & Cukup/ Sedang \\
\hline$<60$ & Kurang \\
\hline
\end{tabular}

Sumber : Asmawi Zainul, Tahun: 2005

Selanjutnya, data observasi keaktifan di analisis dengan cara menghitung persentase keaktifan belajar matematika siswa. Berdasarkan teknik kategorisasi, mengkategorikan keaktifan belajar sebagai berikut : 
Tabel 2. Kategori Tingkat Keaktifan Belajar Siswa

\begin{tabular}{cc}
\hline $\begin{array}{c}\text { Rentang Persentase Hasil } \\
\text { Keaktifan Belajar } \\
\text { Matematika }(\boldsymbol{\%})\end{array}$ & Kategori \\
\hline $\mathrm{P}>80$ & Sangat Aktif \\
\hline $60<\mathrm{P} \leq 80$ & Aktif \\
\hline $40<\mathrm{P} \leq 60$ & Cukup \\
\hline $20<\mathrm{P} \leq 40$ & Kurang \\
\hline $\mathrm{P}<20$ & Sangat Kurang \\
\hline
\end{tabular}

Sumber : Suharsimi Arikunto, Tahun: 2006

Analisis hasil lembar observasi keaktifan belajar siswa dilakukan dengan cara berikut:

1) Menjumlahkan skor disetiap pertemuan sesuai denganacuan yang ditetapkan, kemudian menghitung persentase lembar observasi keaktifan balajar dengan menggunakan rumus sebagai berikut:

Persentase $=\frac{\text { jumlah skor }(5 \text { kali pertemuan })}{\text { jumlah skor maksimal (5 kali pertemuan) }} \times 100 \%$

2) Setelah mendapat persentase hasil lembar observasi keaktifan belajar siswa, maka dilakukan pemberian kategori skor keaktifan belajar siswa.

\section{B. Statistika inferensial}

Statistika inferensial digunakan untuk menguji hipotesis penelitian. Untuk keperluan tersebut dalam mencari apakah keaktifan belajar siswa akibat penerapan model pembelajaran kooperatif tipe Team Assistend Individualization (TAI) mempunyai pengaruh terhadap hasil belajar matematika. Adapun persyaratan uji analisis yang digunakan adalah sebagai berikut:

\section{1) Uji Normalitas}

Uji Normalitas digunakan untuk mengetahui kenormalan terhadap hasil belajar siswa yang diajar menggunakan model pembelajaran kooperatif tipe Team Assistend Individualization (TAI), untuk mengetahui kenormalan data maka digunakan program SPSS 22. Data yang berdistribusi normal apabila nilai probability value (sig) $>\alpha=0,05$.

\section{2) Uji linearitas}

Uji linearitas digunakan untuk mengetahui apakah keaktifan belajar siswa akibat penerapan model pembelajaran kooperatif tipe Team Assistend Individualization (TAI) terdapat hubungan linear secara signifikan terhadap hasil belajar matematika siswa. Uji linearitas dilakukan dengan maenggunakan program 
SPSS versi 22 dengan perangkat deviation from linearity. Dengan pengujian signifikansinya yaitu jika $p$.sig $>\alpha$ dengan taraf signifikan $\alpha=0,05$, maka memiliki hubungan linear, sebaliknya jika p.sig $<\alpha$ maka hubungannya tidak bersifat linear. Pengujian hipotesis yaitu:

$$
\begin{aligned}
& \mathrm{H}_{0}=\text { Regresi linear } \\
& \mathrm{H}_{1}=\text { Regresi non regresi }
\end{aligned}
$$

\section{3) Uji regresi linear sederhana}

Uji regresi linear sederhana digunakan untuk pengujian hipotesis apakah keaktifan belajar siswa akibat penerapan model pembelajaran kooperatif tipe Team Assistend Individualization (TAI) mempengaruhi hasil belajar matematika siswa. Jika nilai signifikani < dari nilai 0,05 , artinya variabel bebas berpengaruh secara signifikan terhadap variabel terikat, begitupun dengan sebaliknya jika nilai signifikani > dari nilai 0,05 , artinya variabel bebas tidak berpengaruh secara signifikan terhadap variabel terikat.

Adapun rumus persamaan regresi linear sederhana yaitu : $\mathrm{Y}^{\prime}=a+b x$

Keterangan:

$\mathrm{Y}^{\prime}=$ Variabel terikat (hasil belajar matematika siswa)

$a=$ Nilai konstanta

$b x=$ Nilai penurunan atau peningkatan variabel bebas yaitu keaktifan belajar siswa akibat model pembelajaran kooperatif tipe TAI.

Adapun kriteria pengujian hipotesis yaitu sebagai berikut :

$\mathrm{H}_{1}=$ Ada pengaruh keaktifan belajar siswa akibat diterapkan model kooperatif tipe Team Assistend Individualization (TAI) terhadap hasil belajar matematika siswa kelas VII SMP Negeri 4 Satap Bungoro.

$\mathrm{H}_{0}=$ Tidak ada pengaruh keaktifan belajar siswa akibat diterapkan model kooperatif tipe Team Assistend Individualization (TAI) terhadap hasil belajar matematika siswa kelas VII SMP Negeri 4 Satap Bungoro.

Adapun kriteria pengujian hipotesis jika di lihat dari aspek nilai signifikan dan nilai F sebagai berukut :

Jika nilai signifikan > dari nilai 0,05 maka $\mathrm{H}_{0}$ ditolak

Jika nilai signifikan < dari nilai 0,05 maka $\mathrm{H}_{1}$ diterima

Jika $\mathrm{F}_{\text {hitung }}>\mathrm{F}_{\text {tabel }}$ maka $\mathrm{H}_{0}$ ditolak

Jika $\mathrm{F}_{\text {hitung }}<\mathrm{F}_{\text {tabel }}$ maka $\mathrm{H}_{1}$ ditolak 
Penelitian ini melibatkan dua variabel diantaranya variabel bebas yaitu keaktifan belajar siswa akibat penerapan model pembelajaran kooperatif tipe Team Assisted Individualization (TAI) dan variabel terikat yaitu hasil belajar siswa. Data observasi dan hasil tes diperoleh data berupa skor keaktifan siswa dan skor hasil belajar, kemudian data tersebut dianalisis dengan menggunakan statistik deskriptif dan statistik inferensial.

\section{PEMBAHASAN}

\section{A. Hasil Analisis Statistik Deskriptif}

Analisis deskriptif dimaksudkan untuk mendeskripsikan atau menggambarkan karakteristik data penelitian tentang keaktifan dan hasil belajar matematika siswa akibat penerapan pembelajaran kooperatif tipe Team Assisted Individualization (TAI). Hasil analisis tersebut diurailkan sebagai berikut:

a. Hasil belajar siswa kelas VII akibat pembelajaran kooperatif tipe Team Assisted Individualization (TAI)

Data hasil belajar siswa kelas VII SMP Negeri 4 Satap Bungoro yang di ajar dengan model pembelajaran kooperatif tipe Team Assisted Individualization (TAI) di sajikan lengkap pada lampiran hasil analisis data yang di rangkum pada tabel 4.1 berikut:

Tabel 3. Statistik Deskriptif Skor Hasil Belajar Matematika Siswa Kelas VII SMP Negeri 4 Satap Bungoro Tahun Ajaran 2016/2017.

\begin{tabular}{cc}
\hline Statistik & Nilai Statistik \\
\hline Subjek Penelitian & 27 \\
Skor Tertinggi & 95 \\
Skor Terendah & 54 \\
Rentang & 41 \\
Skor rata-rata & 80,56 \\
Median & 81,00 \\
Modus & 77 \\
Varians & 114,103 \\
Standar Deviasi & 10,682 \\
\hline
\end{tabular}

Sumber : Data Primer, Tahun: 2017

Pada tabel diatas terlihat bahwa skor rata-rata hasil belajar yang diperoleh siswa adalah 80,56 dengan standar deviasi 10,682. Selanjutnya jika data hasil belajar siswa tersebut pada tabel 4.3 dikelompokkan kedalam empat kategori (berdasarkan hasil pengkategorian guru matematika SMP Negeri 4 Satap Bungoro), maka diperoleh daftar distribusi frekuensi pada tabel 4 berikut: 
Tabel 4. Deskripsi Frekuensi dan Peresentase Skor Hasil Siswa Kelas VII SMP Negeri 4 Satap Bungoro Tahun Ajaran 2016/2017.

\begin{tabular}{|c|c|c|c|}
\hline $\begin{array}{c}\text { Interval } \\
\text { Skor }\end{array}$ & $\begin{array}{c}\text { Skor } \\
\text { Kategori }\end{array}$ & frekuensi & $\begin{array}{c}\text { Peresentase } \\
(\%)\end{array}$ \\
\hline $80-100$ & Sangat & 14 & 51,82 \\
\hline $70-79$ & Baik & 8 & 29,63 \\
\hline $60-69$ & Baik & 4 & 14,82 \\
\hline$<60$ & $\begin{array}{l}\text { Cukup } \\
\text { Kurang }\end{array}$ & 1 & 3,73 \\
\hline \multicolumn{2}{|c|}{ Jumlah } & 27 & $100 \%$ \\
\hline
\end{tabular}

Sumber : Data Primer, Tahun: 2017

Dari tabel 4 terlihat bahwa tidak ada siswa yang memperoleh hasil belajar kategori kurang sebanyak 1 siswa (3,73\%), siswa yang memperoleh hasil belajar kategori cukup sebanyak 4 siswa $(14,82 \%)$, siswa yang memperoleh hasil belajar kategori baik sebanayak 8 siswa $(29,63 \%)$ dan siswa yang memperoleh hasil belajar kategori sangat baik sebanyak 14 siswa (51,82\%). Dengan demikian, hasil belajar siswa akibat penerapan model pembelajaran kooperatif tipe Team Assistend Individualization (TAI) berada dalam kategori sangat baik.

Selanjutnya data hasil belajar siswa akibat penerapan model pembelajaran kooperatif tipe Team Assistend Individualization (TAI) di analisis berdasarkan kriteria ketuntasan pada tabel 5 berikut :

Tabel 5. Deskripsi Ketuntasan Hasil Belajar Matematika Siswa Kelas VII SMP Negeri 4 Satap Bungoro Tahun Ajaran 2016/2017.

\begin{tabular}{|c|c|c|c|}
\hline $\begin{array}{l}\text { Interval } \\
\text { skor }\end{array}$ & $\begin{array}{c}\text { Kategori } \\
\text { ketuntasan }\end{array}$ & Frekuensi & $\begin{array}{c}\text { Persentasi } \\
(\%)\end{array}$ \\
\hline $75-100$ & Tuntas & 21 & 77,78 \\
\hline $0-74$ & $\begin{array}{l}\text { Tidak } \\
\text { Tuntas }\end{array}$ & 6 & 22,22 \\
\hline \multicolumn{2}{|c|}{ Jumlah } & 27 & $100 \%$ \\
\hline
\end{tabular}

Sumber : Data Primer, Tahun: 2017

Dari tabel 5 terlihat bahwa yang tergolong kategori tidak tuntas sebanyak 6 siswa $(22,22 \%)$, sedangkan yang memenuhi kriteria ketuntasan sebanyak 21 siswa (77,78\%), sehingga dapat dikatakan bahwa model pembelajaran kooperatif tipe Team Assistend Individualization (TAI) pada siswa kels VII SMP Negeri 4 Satap Bungoro, memenuhi kriteria ketuntasan hasil pembelajaran matematika. 


\section{b. Keaktifan belajar siswa kelas VII dalam pembelajaran kooperatif tipe team assisted individualization (TAI)}

Berdasarkan hasil analisis deskriptif keaktifan belajar matematika siswa kelas VII SMP Negeri 4 satap Bungoro yang diajar dengan menggunakan model pembelajaran kooperatif tipe Team Assisted Individualization (TAI) dapat dipaparkan pada tabel 6 dan perhitungan selengkapnya pada lampiran analisis data.

Tabel 6 Statistik Skor Keaktifan Belajar Matematika Siswa Kelas VII SMP Negeri 4 Bungoro Tahun ajaran 2016/2017.

\begin{tabular}{c|c}
\hline Statistik & Nilai statistik \\
\hline Subjek Penelitian & 27 \\
Skor Tertinggi & 97 \\
Skor Terendah & 57 \\
Rentang & 40 \\
Skor Rata-Rata & 75,26 \\
Median & 77,00 \\
Modus & 77 \\
Varians & 118,199 \\
Standar Deviasi & 10,872 \\
\hline
\end{tabular}

Sumber : Data Primer, Tahun: 2017

Jika data keaktifan siswa pada tabel 4.4 dikelompokkan kedalam empat kategori (berdasarkan hasil pengkategorian guru matematika SMP Negeri 4 Satap Bungoro), maka diperoleh daftar distribusi frekuensi seperti pada tabel 7 berikut

Tabel 7. Distribusi Frekuensi dan Peresentase Skor Keaktifan Belajar Matematika Siswa Kelas VII SMP Negeri 4 Satap Bungoro Tahun Ajaran 2016/2017

\begin{tabular}{|c|c|c|c|}
\hline $\begin{array}{l}\text { Rentang } \\
\text { Skor }\end{array}$ & Skor Kategori & Frekuensi & $\begin{array}{c}\text { Peresentase } \\
(\%)\end{array}$ \\
\hline $\mathrm{P}>80$ & Sangat Aktif & 8 & 29,62 \\
\hline $60<\mathrm{P} \leq 80$ & Aktif & 15 & 55,55 \\
\hline $40<\mathrm{P} \leq 60$ & Cukup Aktif & 4 & 14,83 \\
\hline $20<\mathrm{P} \leq 40$ & Kurang Aktif & 0 & 0 \\
\hline $\mathrm{P}<20$ & $\begin{array}{c}\text { Sangat Kurang } \\
\text { Aktif }\end{array}$ & 0 & 0 \\
\hline \multicolumn{2}{|c|}{ Jumlah } & 27 & $100 \%$ \\
\hline
\end{tabular}

Sumber : Data Primer, Tahun: 2017

Dari tabel 7 menunjukkan bahwa dari 27 siswa kelas VII SMP Negeri 4 Satap Bungoro yang mengikuti pembelajaran dengan model pembelajaran kooperatif tipe team assisted individualization (TAI), tampak bahwa keaktifan belajar siswa yang tergolong kategori sangat kurang aktif dan kurang aktif (0\%), dan cukup aktif sebanyak 4 siswa (14,83\%), siswa yang , siswa yang aktif sebanyak 15 siswa 
$(55,55 \%)$, sangat aktif sebanyak 8 siswa $(29,62 \%)$. Menunjukkan bahwa keaktifan belajar matematika siswa berada pada kategori aktif.

\section{B. Hasil analisis statistik inferensial}

Pengujian hipotesis menggunakan statistik inferensial yaitu dengan menggunakan uji regresi linear sederhana, sebelum dilakukan uji regresi linear sederhana terlebih dahulu dilakukan uji persyaratan analisis sebagai berikut :

\section{a. Uji Normalitas}

Uji Normalitas bertujuan untuk mengetahui apakah sebaran dari masingmasing skor berdistribusi normal atau tidak. Apabila data mempunyai distribusi normal, analisis untuk menguji hipotesis dapat dilakukan. Dalam penelitian ini pengujian normalitas data menggunakan uji sampel Kolmogorov-Smirnov dengan bantuan program SPSS versi 22, sebab metode ini dirancang untuk menguji keselarasan pada data yang kontinyu. Berdasarkan lampiran tampak bahwa besar nilai p. sig. keaktifan belajar matimatika siswa sebesar 0,200 . Secara matematis dapat dituliskan 0,200>0,05 dan hasil belajar matematika siswa sebesar 0,123. Secara matematis dapat dituliskan 0,123 >0,05. Dari hasil pengujian, seluruh data signifikansi berada diatas taraf signifikansi 0,05 , hal ini memberi makna bahwa seluruh data berdistribusi secara normal. Jadi pengujian normalitas terpenuhi.

\section{b. Uji Linearitas}

Uji Linearitas dimaksudkan untuk mengetahui pola hubungan antara masingmasing variabel bebas dengan variabel terikat apakah berbentuk linier atau tidak, dimana $\mathrm{H}_{0}$ (hubungan variabel linear) dan $\mathrm{H}_{1}$ (hubungan variabel non linear). Uji Linearitas dapat diketahui dengan menggunakan program SPSS Versi 22 dengan perangkat Test For Linearity. Data diolah dengan menggunakan bantuan program SPSS versi 22. Taraf signifikansi ditentukan sebesar 0,05. Berdasarkan hasil analisis pada lampiran dapat diketahui bahwa nilai signifikansi pada deviation from linearity diperoleh nilai p.sig. sebesar 0,725 . Nilai tersebut lebih besar dari pada taraf signifikansi yang ditentukan, yaitu sebesar 0,05 . Karena $0,725>0,05$ hal ini menunjukkan $\mathrm{H}_{0}$ diterima (regresi linear). Jadi dapat disimpulkan bahwa terdapat hubungan antara variabel bebas dengan terikat adalah linear dan pengujian linearitas terpenuhi.

\section{c. Uji Regresi Linear Sederhana}

Pengujian hipotesis dilakukan untuk membuktikan benar tidaknya hipotesis yang diajukan, karena pada dasarnya hipotesis adalah pernyataan yang masih lemah 
kebenarannya atau dugaan yang sifatnya sementara. Pengujian hipotesis dalam penelitian ini menggunakan analisis regresi linear sederhana. Analisis tersebut digunakan untuk mengetahui koefisien pengeruh baik secara sendiri-sendiri maupun secara bersama-sama antara variabel bebas (keaktifan siswa) terhadap variabel terikat (hasil belajar siswa). Adapun hipotesis yang diuji adalah sebagai berikut :

$\mathrm{H}_{1}=$ Ada pengaruh keaktifan belajar siswa akibat diterapkan model kooperatif tipe Team Assistend Individualization (TAI) terhadap hasil belajar matematika siswa kelas VII SMP Negeri 4 Satap Bungoro.

$\mathrm{H}_{0}=$ Tidak ada pengaruh keaktifan belajar siswa akibat diterapkan model kooperatif tipe Team Assistend individualization (TAI) terhadap hasil belajar matematika siswa kelas VII SMP Negeri 4 Satap Bungoro.

\section{KESIMPULAN DAN SARAN}

\section{A. Kesimpulan}

Kesimpulan dari keseluruhan uraian dalam skripsi ini maka diambil kesimpulan yang merupakan gambaran menyeluruh dari hasil pembahasan, yang dapat dikemukakan sebagai berikut :

1. Keaktifan siswa akibat penerapan model pembelajaran kooperatif tipe Team Assisted Individualization (TAI) di kelas $\mathrm{VII}_{3}$ SMP Negeri 4 Satap Bungoro dalam kategori sangat aktif sebesar 29,62\% dengan 8 siswa, kategori aktif sebesar 55,55\% dengan 15 siswa, siswa yang memperoleh kategori cukup aktif sebesar 14,83\% dengan 4 siswa, dengan kurang aktif dan sangat kurang aktif tidak ada dengan demikian dapat disimpulkan bahwa keaktifan siswa kelas VII termasuk dalam kategori aktif yang dilihat dari nilai rata-rata keaktifan belajar siswa yaitu 75,26 .

2. Hasil belajar siswa akibat penerapan model pembelajaran kooperatif tipe team assisted individualization (TAI) di kelas $\mathrm{VII}_{3}$ SMP Negeri 4 Satap Bungoro dalam kategori Sangat baik sebesar 51,82\% dengan 14 siswa, kategori baik sebesar 29,63\% dengan 8 siswa, kategori cukup 14,82\% dengan 4 siswa, dan kategori kurang sebesar 3,73\% dengan 1 siswa. Dengan demikian dapat disimpulkan bahwa hasil belajar siswa kelas VII termasuk dalam kategori sangat tinggi yang dilihat dari nilai rata-rata hasil belajar siswa yaitu 80,56.

3. Terdapat pengaruh yang signifikan antara keaktifan belajar siswa akibat penerapan model pembelajaran kooperatif tipe Team Assisted Individualization (TAI) terhadap 
hasil belajar siswa kelas VII dengan nilai $\mathrm{F}_{\text {hitung }}>\mathrm{F}_{\text {tabel }}(6,965>4,24)$, dengan taraf signifikansi 0,05 , sedangkan $\mathrm{R}^{2}=0,137$. Pengaruh keaktifan siswa akibat penerapan model pembelajaran kooperatif tipe Team Assistend Individualization (TAI) terhadap hasil belajar siswa kelas VII adalah $13,7 \%$ dan sisanya sebesar $86,3 \%$ dipengaruhi oleh variabel lain yang mempengaruhi hasil belajar siswa.

\section{B. Saran}

Berdasarkan kesimpulan penelitian di atas, ada beberapa saran yang dapat disampaikan, yaitu :

1. Bagi siswa diharapkan dapat aktif dalam kegiatan peembelajaran agar dapat menambah wawasan dan pengetahuan serta dapat meningkatkan hasil belejar.

2. Sehubungan dengan hasil akhir dari penelitian ini, maka perlu diadakan penelitian lebih lanjut dalam skala yang lebih luas dan spesifik agar lebih memperluas pengetahuan tentang pengaruh keaktifan belajar siswa akibat penerapan model pembelajaran kooperatif tipe Team Assisted Individualization (TAI) terhadap hasil belajar siswa.

3. Kepada para peneliti di bidang pendidikan khususnya di bidang matematika untuk melakukan/mengadakan penelitian lain mengenai topik seperti ini terhadap populasi lain dengan mata pelajaran dan tingkat sekolah yang sama atau melakukan penelitian dengan lebih banyak variabel, baik yang bersumber dari luar diri siswa serta mengkaji lebih dalam faktor-faktor apa yang lebih dominan pengaruhnya terhadap hasil belajar.

4. Disarankan agar dalam melaksanakan proses belajar mengajar guru hendaknya memilih model pembelajaran yang sesuai dengan karakteristik dan tingkat kemampuan siswa dalam menyelesaikan berbagai masalah dalam proses pembelajaran agar lebih mudah menerimah materi pembelajaran khususnya dalam pembelajaran matematika.

\section{DAFTAR PUSTAKA}

Asep Jihad, dkk. 2012. Evaluasi Pembelajaran. Yogyakarta: Multi Pressindo. Asma, Nur. 2006. Model Pembelajaran Kooperatif, Jakarta : Depdiknas.

Daryanto.(2013).Strategi dan tahapan mengajar (bekal keterampilan dasar bagi guru).Bandung : CV Yrama Widya.

Dewi Kristanti, 2014. Upaya Meningkatkan Prestasi Belajar Matematika Materi Bangun Datar Melalui Media Tanaram pada Siswa Kelas VII SMP Negeri 25 
Surabaya. E-Jurnal Dinas Pendidikan Kota Surabaya, Volume 4. Diakses pada tanggal 29 September 2014.

Djamarah, Syaiful Bahri dan Aswan Zain. 2009. Strategi Belajar Mengajar. Jakarta: Rineka Cipta

Endang Mulyatiningsih, 2013. Metode Penelitian Terapan Bidang Pendidikan. Bandung: Alfabeta.

Erman Suherman, dkk. 2003. Strategi Pembelajaran Matematika Kontemporer. Bandung: UPI.

Isriani Hardini dan Dewi Puspitasari, 2012. Strategi Pembelajaran Terpadu (Teori, Konsep dan Implementasi). Yogyakarta: Familia

Karyasa, I N. R., Salain, I M. A.K., \& Nadiasa, M. (2011). Analisis faktor- faktor yang mempengaruhi gagal lelang pengadaan barang dan jasa pemerintah secara elektronik (e-procurement) di Kabupaten Badung. 